\title{
FACTORS AFFECTING THE THERMAL ACTIVATION OF NEOSARTORYA FISCHERI IN PINEAPPLE AND PAPAYA NECTARS
}

\author{
Adriana Paula Slongo; Gláucia Maria Falcão de Aragão* \\ Departamento de Engenharia Química e Engenharia de Alimentos, Universidade Federal de Santa Catarina, \\ Florianópolis, SC, Brasil
}

Submitted: May 02, 2005; Returned to authors for corrections: October 31, 2005; Approved: April 03, 2006

\begin{abstract}
In this research factors that influence the activation of Neosartorya fischeri ascospores (heating medium, temperature of production and age of the ascospores) were studied. The heating medium used was pineapple and papaya nectars at different ratios ( ${ }^{\circ}$ Brix/acidity). Lower activation times were observed for the $N$. fischeri ascospores in pineapple and papaya nectars under the conditions of temperature and production age of $25^{\circ} \mathrm{C}$ for 1 month and using ratios of the heating medium of 10 for pineapple nectar and 26 for papaya nectar. In these cases, the activation time was 5 minutes for the pineapple nectar and 10 minutes for the papaya nectar at $85^{\circ} \mathrm{C}$. For the ascospores produced at $35^{\circ} \mathrm{C}$ over three months, heated in pineapple nectar at a ratio of 38 and in papaya nectar at a ratio of 66, the longest activation times of 15 and 20 minutes, respectively, were observed. The statistical analysis showed that the factors which had the most influence in the activation time of the ascospores were the ratio and the production temperature of ascospores.
\end{abstract}

Key words: ascospores, ratio, Neosartorya fischeri, activation

\section{INTRODUCTION}

The study of thermal resistant molds is important because molds are frequently responsible for the deterioration of different juices and nectars, mainly due to their ability to survive heat treatments commonly applied in the nectar industry.

Ascospores of molds belonging to the genera Neosartorya, Byssochlamys, Talaromyces and Eupenicillium can often survive commercial thermal treatments, become activated, grow and cause spoilage $(9,13,14)$. The extremely resistant species Byssochlamys fulva, Talaromyces flavus and Neosartorya fischeri serve as standards for spore resistance and their absence indicates the quality of sterilization processes $(6,7)$. It is well known that for a given increase in temperature, the rate of destruction of microorganisms increases faster than the rate of destruction of nutrients and sensory components (1).
Ascospores produced by thermal resistant molds develop, with time, a dormant state that can only be broken with a sublethal thermal treatment that will allow their germination and growth under favorable conditions. This treatment is called activation $(4,16)$. The pasteurization normally applied to acid vegetal products, activates dormant ascospores that will initiate the germination process, causing deterioration in the final product (8). Mainly the genus, but also the strain, of the fungus determines whether heat activation is crucial for germination or whether it only increases the number of spores germinating if transferred to a favorable environment $(6,16)$. It has long been known that thermal resistant ascospores possess a dormancy that can be broken by heat shock. In this paper the influence of heating medium ratio, and the age and temperature of the ascospores production on the heat activation of $N$. fischeri ascospores was investigated in papaya and pineapple nectars as the heating medium.

*Corresponding Author. Mailing address: Departamento de Engenharia Química e Engenharia de Alimentos, Universidade Federal de Santa Catarina. 88040-900, Florianópolis, SC, Brasil. Tel.: (+5548) 331-9930, Fax: (+5548) 331-9687. E-mail: glaucia@enq.ufsc.br 


\section{MATERIALS AND METHODS}

\section{Fractional Experimental Planning}

The combined effect of the heating medium ratio, the temperature and the ascospores production age on the activation time of $N$. fischeri was evaluated by a $2^{3}$ an experimental planning, with triplicate at the central point. The experiments are described in Tables 1 and 2 for pineapple and papaya nectars, respectively.

The ascospores production temperatures and ages were the same for both nectars $\left(25^{\circ} \mathrm{C}\right.$ for 1 and 3 months, $30^{\circ} \mathrm{C}$ for 2 months and $35^{\circ} \mathrm{C}$ for 1 and 3 months). Different heating medium ratios were used for each nectar (26, 46 and 66 for papaya nectar and 10, 24 and 38 for pineapple nectar), in accordance with the range used in the industry.

Table 1. Levels of the factors used in the experimental design for pineapple nectar.

\begin{tabular}{cccc}
\hline Factors & \multicolumn{3}{c}{ Level } \\
\cline { 2 - 4 } & -1 & 0 & +1 \\
\hline Ascospore production temperature $\left({ }^{\circ} \mathrm{C}\right)$ & 25 & 30 & 35 \\
Heating media Ratio $\left({ }^{\circ}\right.$ Brix/acidity) & 10 & 24 & 38 \\
Ascospore production age (month) & 1 & 2 & 3 \\
\hline
\end{tabular}

Table 2. Levels of the factors used in the experimental design for papaya nectar.

\begin{tabular}{cccc}
\hline Factors & \multicolumn{3}{c}{ Level } \\
\cline { 2 - 4 } & -1 & 0 & +1 \\
\hline Ascospore production temperature $\left({ }^{\circ} \mathrm{C}\right)$ & 25 & 30 & 35 \\
Heating media Ratio $\left({ }^{\circ}\right.$ Brix/acidity) & 26 & 46 & 66 \\
Ascospore production age (month) & 1 & 2 & 3 \\
\hline
\end{tabular}

\section{Preparation of Ascospores}

Ascospores were grown over 1 and 3 months at $25^{\circ} \mathrm{C}$ and $35^{\circ} \mathrm{C}$ and over 2 months at $30^{\circ} \mathrm{C}$ on Malt Extract Agar (Biolife, $\mathrm{SP}, \mathrm{Br}$ ), (MEA), pH 5.4, prepared according to Pitt and Hocking (11). The biomass was filtered through a sterile gauze and washed twice with water after centrifugation. The final suspension obtained was diluted with enough sterile water to give a suspension of $10^{6}$ ascospores $/ \mathrm{mL}$. The ascospores were stored under refrigeration in flasks containing glass beads.

\section{Acidity determination of fruit nectars}

For the acidity determination of fruit nectars $1 \%$ phenolphthalein solution and $0.1 \mathrm{~N} \mathrm{NaOH}$ (Nuclear, SP, Br) standardized with its respective correction factor were used. The result is expressed as percentage of acidity, calculated according to the predominant acid in the fruit which was citric $\operatorname{acid}(\mathrm{m} / \mathrm{m})$ for the studied nectars $(12)$.

\section{${ }^{\circ}$ Brix determination}

The determination of the content of total soluble solids ( ${ }^{\circ} \mathrm{Brix}$ ) was carried out with a refractometer (ABBÉ-refractometerInstruterm). The results were expressed as grams of total soluble solids contained in 100 grams of sample.

\section{Ratio determination $\left({ }^{\circ} \mathrm{Brix} / \mathrm{acidity}\right)$}

Once the ${ }^{\circ}$ Brix and the acidity had been determined, the ratio could be calculated as the relation between them.

\section{Obtention of ratio values}

To give the low ratio values, firstly the ${ }^{\circ} \mathrm{Brix}$ of the nectars was fixed $\left(12^{\circ} \mathrm{Brix}\right.$ for pineapple and $13^{\circ} \mathrm{Brix}$ for papaya) and a $20 \%$ citric acid solution was then added to the medium until the acidity of the medium reached 1.2 for pineapple nectar and 0.5 for papaya nectar. The ratio was determined through the relation between the ${ }^{\circ}$ Brix and the acidity of the nectars, measured after the addition of the citric acid. The ratio values were 10 for pineapple nectar and 26 for papaya nectar.

To give the high ratio values, firstly, the natural acidity of the nectars was determined ( 0.5 for pineapple nectar and 0.25 for papaya nectar). A $60 \%$ sugar solution was then added to the medium until the ${ }^{\circ}$ Brix reached 19 for the pineapple nectar and 18.5 for the papaya nectar. The ratio was determined through the relation between the ${ }^{\circ} \mathrm{Brix}$, adjusted by sugar addition, and the nectar acidity. The ratios were 38 and 66 for pineapple and papaya nectars, respectively. The ratios of 24 and 46 for pineapple and papaya, respectively, represent the natural nectar ratios.

\section{Determination of the optimum conditions for the activation of the ascospores}

For the determination of the optimum conditions for the activation of the ascospores, the temperature was kept at $85^{\circ} \mathrm{C}$ (3) for the following time periods: 0 (control), 5, 10, 15 and 20 minutes. Pineapple or papaya nectar was used as the heating medium. The method applied was that which employs sealed TDT tubes. For the heating, $0.2 \mathrm{~mL}$ of the ascospore suspension were added to $1.8 \mathrm{~mL}$ of pineapple or papaya nectar in TDT tubes sealed with a $\mathrm{O}_{2} / \mathrm{GLP}$ blowtorch. The tubes were heated in a thermostatically controlled water bath (TE- $184 \pm 0.1^{\circ} \mathrm{C}$ - Tecnal, $\mathrm{SP}, \mathrm{Br})$ at $85^{\circ} \mathrm{C}$. Each experiment was done in duplicate and the means were expressed as average from two determinations.

\section{Viable counts}

To determine the number of ascospores that survived, the suspensions were diluted as needed in duplicate plates and 
pour plated using MEA (pH 5.4) containing $50 \mathrm{mg} / \mathrm{L}$ of rose bengal. Plates were incubated at $30^{\circ} \mathrm{C}$ and counted after three days. The count was expressed as $\mathrm{CFU} / \mathrm{mL}$.

\section{RESULTS AND DISCUSSION}

The optimum activation times observed for the different treatments are presented in Table 3 for pineapple nectar and in Table 4 for papaya nectar.

In Table 3 the influence of the factors under study on the activation of the ascospores in pineapple nectar can be seen. When the ratio of the heating medium was 38 , the activation time was 10 or 15 minutes, whereas when the ratio was 10 , it was 5 or 10 minutes.

Table 3. Activation treatments for Neosartorya fischeri in pineapple nectar.

\begin{tabular}{cccc}
\hline $\begin{array}{c}\text { Ascospores } \\
\text { production } \\
\text { temperature }\left({ }^{\circ} \mathrm{C}\right)\end{array}$ & $\begin{array}{c}\text { Ascospores } \\
\text { production } \\
\text { time (months) }\end{array}$ & $\begin{array}{c}\text { Nectar } \\
\text { ratio }\end{array}$ & $\begin{array}{c}\text { Treatment to } \\
\text { obtain the } \\
\text { optimum } \\
\text { activation }\end{array}$ \\
\hline 30 & 2 & 24 & $85^{\circ} \mathrm{C} / 10$ minutes \\
25 & 1 & 10 & $85^{\circ} \mathrm{C} / 5$ minutes \\
25 & 1 & 38 & $85^{\circ} \mathrm{C} / 10$ minutes \\
25 & 3 & 10 & $85^{\circ} \mathrm{C} / 5$ minutes \\
25 & 3 & 38 & $85^{\circ} \mathrm{C} / 10$ minutes \\
35 & 1 & 10 & $85^{\circ} \mathrm{C} / 10$ minutes \\
35 & 1 & 38 & $85^{\circ} \mathrm{C} / 10$ minutes \\
35 & 3 & 10 & $85^{\circ} \mathrm{C} / 10$ minutes \\
35 & 3 & 38 & $85^{\circ} \mathrm{C} / 15$ minutes \\
\hline
\end{tabular}

Analyzing the results in Table 4, it can be observed that ascospores which were produced at $35^{\circ} \mathrm{C}$ over 3 months and heated with a heating medium ratio of 66 gave the longest time for the optimum activation $\left(85^{\circ} \mathrm{C} / 20\right.$ minutes). However, when produce at $35^{\circ} \mathrm{C}$ over 1 month with heating medium ratio of 26 , the lowest activation time $\left(85^{\circ} \mathrm{C} / 10\right.$ minutes $)$ was obtained.

The results shown in Tables 3 and 4 were submitted to analysis of variance and estimation of the effects through the software Statistic 6.0. The factors are statistically significant when $\mathrm{p}<0.05$. Table 5 presents the results of the statistical analysis for the response variable time activation of ascospores at the different condition, for pineapple and papaya nectars.

Comparing the results obtained for each nectar, it was verified that, concerning the ratio factor, the highest activstion time increase was found for papaya nectar. The factor production temperature caused the strongest effect in pineapple nectar. For papaya nectar, the production temperature of the ascospores was not significative. The age factor had no significative effect
Table 4. Activation treatments for Neosartorya fischeri in papaya nectar.

\begin{tabular}{cccc}
\hline $\begin{array}{c}\text { Ascospores } \\
\text { production } \\
\text { temperature }\left({ }^{\circ} \mathrm{C}\right)\end{array}$ & $\begin{array}{c}\text { Ascospores } \\
\text { production } \\
\text { time (months) }\end{array}$ & $\begin{array}{c}\text { Nectar } \\
\text { ratio }\end{array}$ & $\begin{array}{c}\text { Treatment to } \\
\text { obtain the } \\
\text { optimum } \\
\text { activation }\end{array}$ \\
\hline 30 & 2 & 46 & $85^{\circ} \mathrm{C} / 10$ minutes \\
25 & 1 & 26 & $85^{\circ} \mathrm{C} / 10$ minutes \\
25 & 1 & 66 & $85^{\circ} \mathrm{C} / 15$ minutes \\
25 & 3 & 26 & $85^{\circ} \mathrm{C} / 10$ minutes \\
25 & 3 & 66 & $85^{\circ} \mathrm{C} / 15$ minutes \\
35 & 1 & 26 & $85^{\circ} \mathrm{C} / 10$ minutes \\
35 & 1 & 66 & $85^{\circ} \mathrm{C} / 15$ minutes \\
35 & 3 & 26 & $85^{\circ} \mathrm{C} / 10$ minutes \\
35 & 3 & 66 & $85^{\circ} \mathrm{C} / 20$ minutes \\
\hline
\end{tabular}

Table 5. Analysis of variance and estimate of effects for the studied response variable activation time for pineapple and papaya nectars.

\begin{tabular}{ccccc}
\hline \multirow{3}{*}{ Factors } & \multicolumn{4}{c}{ Response variable } \\
\cline { 2 - 5 } & \multicolumn{4}{c}{ Activation time } \\
\cline { 2 - 5 } & \multicolumn{2}{c}{ Pineapple nectar } & \multicolumn{2}{c}{ Papaya nectar } \\
& Effect & Value- $\mathrm{p}$ & Effect & Value- $\mathrm{p}$ \\
\hline$(1)-\mathrm{T}^{\mathrm{O}} \mathrm{C}$ & $\mathbf{3 . 7 5}$ & $\mathbf{0 . 0 0 6 0 1 2}$ & 1.25 & 0.51396 \\
$(2)-$ Age & 1.25 & 0150944 & 1.25 & 0.51396 \\
$(3)-$ Ratio & $\mathbf{3 . 7 5}$ & $\mathbf{0 . 0 0 6 0 1 2}$ & $\mathbf{6 . 2 5}$ & $\mathbf{0 . 0 0 2 3 4 2}$ \\
\hline
\end{tabular}

for both nectars. On analyzing only the ratio factor, it was observed that the increase in the activation time resulting from the change from a lower to a higher level, for the papaya nectar, was approximately $6.25 \%$, whereas, for pineapple nectar, it was $3.25 \%$. The same trend was noted for the temperature of ascospore production which, for the pineapple nectar, caused an activation time increase of $3.25 \%$.

Figs. 1 and 2 present the response surface for pineapple nectar and papaya nectar, respectively, which were established for the time activation at $85^{\circ} \mathrm{C}$, with the factors ratio versus ascospore production temperature. It was observed that the mold $N$. fischeri presented higher activation time in the heating media which had the highest ratio value, for both nectars. This can be explained by the fact that, in the assays carried out with the lower ratios, the addition of citric acid solution to the heating media in order to reach the desired ratio was necessary.

These results are in agreement with Splitsttoesser and Splitsttoesser (17) who found that the activation rate of 


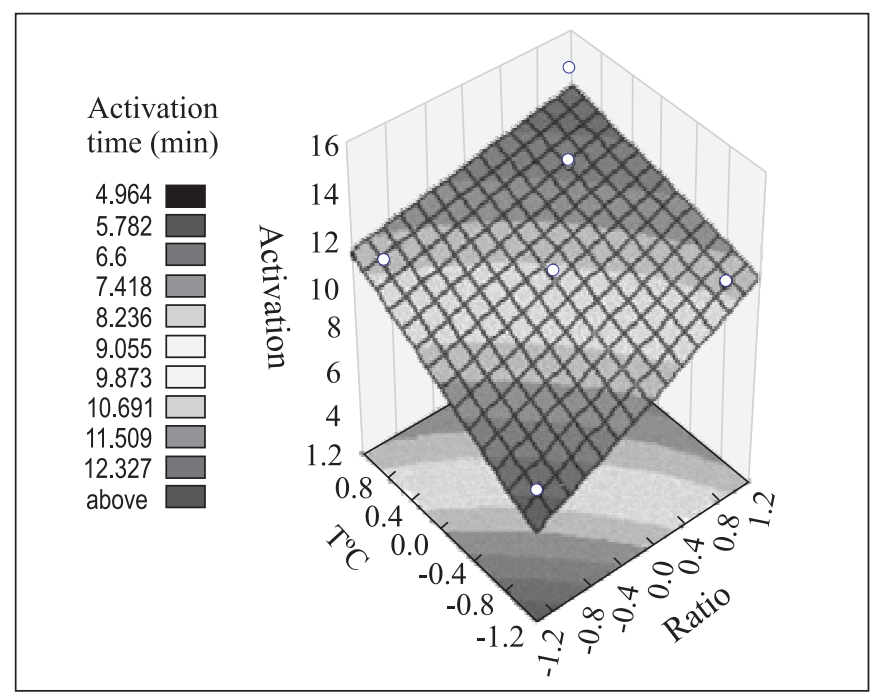

Figure 1. Response surface obtained for ratio versus ascospore production temperature, for the response variable activation time at $85^{\circ} \mathrm{C}$, for pineapple nectar.

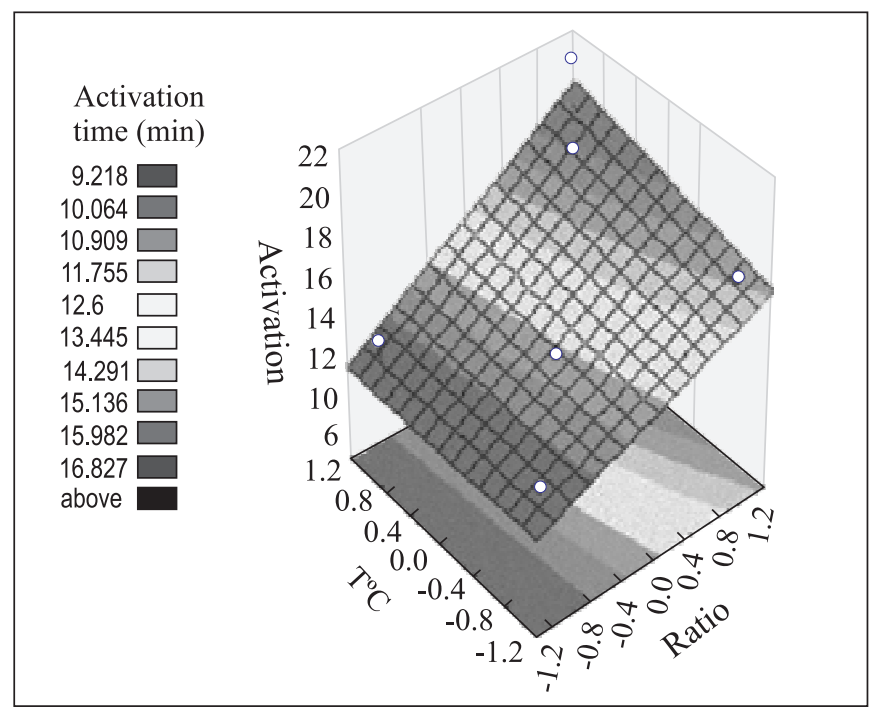

Figure 2. Response surface obtained for ratio versus ascospore production temperature, for the response variable activation time at $85^{\circ} \mathrm{C}$, for papaya nectar.

Byssochlamys nivea and Aspergillus (N. fischeri) ascospores was influenced by the heating medium conditions. The time for activation in the mediums with higher soluble solids concentration was longer in comparison with the mediums with lower soluble solids concentration.

Salomão (15) studied $N$. fischeri ascospores produced at $30^{\circ} \mathrm{C}$ over 1 month and using, as the heating medium, apple nectar ( $\mathrm{pH} 3.5$ and ratio 48) and obtained the optimum activation time of 10 minutes. This value is lower than that found in this study for the assays carried out with ratio of 46 in papaya nectar. Since the ratios of the two heating mediums are almost the same, there may be some influence from other factors, apart from the heating medium and the presence of soluble solids, in the activation of these ascospores.

It was observed, especially for papaya nectar (Fig. 2), that the longest time of ascospore production (3 months) led to an increase in the activation time. This is in agreement with Marcolino (10), who worked with thermal resistant $N$. fischeri isolates from a grape beverage processing line ( $\mathrm{pH} 3.0$ and $\left.14^{\circ} \mathrm{Brix}\right)$. The author produced ascospores at $30^{\circ} \mathrm{C}$, with ages of 1 and 3 months and drew curves of activation at $85^{\circ} \mathrm{C}$ for both ages. The results showed an optimum time of activation of 10 and 25 minutes, for 1 and 3 months, respectively. The same activation effect was studied by Baglioni (2) with $N$. fischeri ascospores produced at $30^{\circ} \mathrm{C}$ over 1 and 3 months. The author observed that a longer time ( 20 minutes) at $85^{\circ} \mathrm{C}$ was required for the optimum activation of the ascospores produced over 3 months in comparison with ascospores produced over 1 month (10 minutes).

In this study the data for the activation times for both nectars showed that the longest ascospore production temperature lead to the longest activation times. These results are in agreement with those reported in the literature. Delgado (5) worked with $N$. fischeri ascospores produced at $30^{\circ} \mathrm{C}$ over 1 and 4 months, using distilled water as the heating medium. The author observed that older ascospores (4 months) needed a longer heat exposure time for maximum activation of the ascospores in comparison with younger ones (1 month). It was also noted in this study that ascospores produced at the highest temperatures (30 and $35^{\circ} \mathrm{C}$ ), needed longer heat exposure times for optimum activation if compared with those that were generated at the milder temperature $\left(25^{\circ} \mathrm{C}\right)$.

\section{CONCLUSION}

The results of statistical analysis showed that the $N$. fischeri ascospore activation time is most influenced by the heating medium ratio (for pineapple and papaya nectar), followed by the ascospore production temperature (pineapple nectar). If the medium contains significant concentrations of soluble solids, or rather, high ratio values, the activation time for this mold will also increase due to the protective effect of the solids.

The obtained results are extremely important because there is little data available in the literature comparing different factors concerning optimum ascospore activation of thermal resistant molds. It is important to emphasize there are no studies comparing the effect of different conditions of ascospores production and the heating medium ratio on its optimum activation. These results are important for further studies on the heat resistance of this mold. 


\section{RESUMO}

\section{Fatores que afetam a ativação térmica de Neosartorya fischeri em sucos de abacaxi e mamão}

Nesta pesquisa, foram estudados fatores que influenciam a ativação de ascósporos do fungo termorresistente Neosartorya fischeri (meio de aquecimento, a temperatura de produção e idade dos ascósporos). Os meios de aquecimento utilizados foram sucos de abacaxi e de mamão, em diferentes ratios ( ${ }^{\circ}$ Brix/ acidez) e a temperatura de ativação foi $85^{\circ} \mathrm{C}$. Pôde-se observar que o fungo $N$. fischeri apresentou seus menores tempos de ativação quando presentes no suco de abacaxi e no mamão, nas condições de temperatura e de idade de produção de $25^{\circ} \mathrm{C}$ por 1 mês e o ratio do meio de aquecimento de 10 para suco de abacaxi e de 26 para suco de mamão. Nestes ensaios, o tempo de ativação foi de 5 minutos para suco de abacaxi e 10 minutos para o suco de mamão a $85^{\circ} \mathrm{C}$. Ascósporos produzidos a $35^{\circ} \mathrm{C}$, durante 3 meses e aquecidos em suco de abacaxi com ratio 38 e em suco de mamão com ratio 66 apresentaram os maiores tempos de ativação sendo estes de 15 a 20 minutos, respectivamente. Através de uma análise estatística, verificouse que os fatores que mais influenciaram no tempo de ativação dos ascósporos foram o ratio e a temperatura de produção dos ascósporos.

Palavras-chave: ascósporos, ratio, Neosartorya fischeri, ativação

\section{REFERENCES}

1. Anese, M.; Socvrano, S. Kinetics of thermal inactivation of tomato lipoxygenase. Food Chem., in print, 2005.

2. Baglioni, F. Estudo da ocorrência de fungos filamentosos termorresistentes em polpa de tomate envasada assepticamente. Campinas, 1998, 65p. (Master's dissertation. Post-Gratuate Program in Food Science. UNICAMP).

3. Beuchat, L.R. Extraordinary heat resistance of Talaromyces flavus and Neosartorya fischeri ascospores in fruit products. J. Food Sci., 51(6), 506-1510, 1986.
4. Beuchat, L.R. Thermal tolerance of Talaromyces flavus ascospores as affected by growth medium, age and sugar content in the inactivation. Trans. Brit. Mycolog. Soc., 90(3), 359-364, 1988.

5. Delgado, D.A. Ação esporicida do peróxido de hidrogênio sobre bolores isolados de laminado para embalagens assépticas. Campinas, 2001, 75p. (Doctor's theses. Post-Gratuate Program in Food Science. UNICAMP).

6. Eicher, R.; Ludwig, H. Influence of activation and germination on high pressure inactivation of ascospores of the mould Eurotium repens. Comp. Bioch. Physiol., 131, 595-604, 2002.

7. Eicher, R.; Merkulow, N.; Van Almsick, G.; Ludwig, H. High pressure inactivation kinetics of moulds. High pressure Biology and Medicine. New York, 1998, 65-75p. (University of Rochester Press).

8. Engel, G.; Teuber, M. Heat resistance of Byssochlamys nivea in milk and cream. Int. J. Food Microbiol., 12, 225-234, 1991.

9. Kotzekidou, P. Heat resistance of Byssochlamys nivea, Byssochlamys fulva and Neosartorya fischeri isolated from canned tomato paste. $J$. Food Sci., 62(2), 410-412/437, 1997.

10. Marcolino, V.A. Quantificação de leveduras, bolores comuns e termorresistentes em linha de processamento asséptico de bebida de uva. Campinas, 2003, 70p. (Master's dissertation. Post-Gratuate Program in Food Science. UNICAMP).

11. Pitt, J.I.; Hocking, A.D. Fungi and Food Spoilage. Academic Press, Sydney, 1985, $413 \mathrm{p}$.

12. Pregnolatto, W.; Pregnolatto, N.P. Normas Analíticas do Instituto Adolfo Lutz - Métodos Químicos e Físicos para Análise de Alimentos. Instituto Adolfo Lutz, São Paulo, 1985, 25p.

13. Rajashekhara, E.; Suresh, E.R.; Ethiraj, S. Modulation of thermal resistance of ascospores of Neosartorya fischeri by acidulants and preservatives in mango and grape nectar. Food Microb., 17, 269275, 2000.

14. Salomão, B.C.M.; Massaguer, P.R.; Costa, C.A.; Aragão, G.M.F. Influência de diferentes pHs do meio de aquecimento na resistência térmica de Neosartorya fischeri isolado do processo produtivo de néctar de maçã. Alimentos e Nutrição, 15(1), 7-10, 2004.

15. Salomão, B.C.M. Isolamento, identificação e estudo da resistência térmica de fungos filamentosos termorresistentes em produtos de frutas. Florianópolis, 2002. 54p. (Master's dissertation. Post-Gratuate Program in Food Engineering. UFSC).

16. Splittstoesser, D.F.; Nielsen, P.V.; Churey, J.J. Detection of viable ascospores of Neosartorya. J. Food Prot., 56, 599-603, 1993.

17. Splittstoesser, D.F.; Splittstoesser, C.M. Ascospores of Byssochlamys compared with those of heat resistant Aspergillus. J. Food Sci., 42(3), 685-688, 1977.

18. Tournas, V.; Traxler, R.W. Heat resistance of a Neosartorya fischeri strain isolated from pineapple nectar frozen concentrate. J. Food Prot., 57(9), 814-816, 1994. 